\title{
QUEEN'S
UNIVERSITY
BELFAST
}

\section{Pyrolysis Kinetic Modeling of a Poly(ethylene-co-vinyl acetate) Encapsulant Found in Waste Photovoltaic Modules}

Farrell, C., Osman, A. I., Harrison, J., Vennard, A., Murphy, A., Doherty, R., Russell, M., Kumaravel, V., AlMuhtaseb, A. H., Zhang, X., Abu-Dahrieh, J. K., \& Rooney, D. W. (2021). Pyrolysis Kinetic Modeling of a Poly(ethylene-co-vinyl acetate) Encapsulant Found in Waste Photovoltaic Modules. Industrial \& Engineering Chemistry Research. https://doi.org/10.1021/acs.iecr.1c01989

Published in:

Industrial \& Engineering Chemistry Research

Document Version:

Publisher's PDF, also known as Version of record

Queen's University Belfast - Research Portal:

Link to publication record in Queen's University Belfast Research Portal

\section{Publisher rights}

Copyright 2021 the authors. Published by American Chemical Society

This is an open access article published under a Creative Commons Attribution License (https://creativecommons.org/licenses/by/4.0/), which permits unrestricted use, distribution and reproduction in any medium, provided the author and source are cited.

\section{General rights}

Copyright for the publications made accessible via the Queen's University Belfast Research Portal is retained by the author(s) and / or other copyright owners and it is a condition of accessing these publications that users recognise and abide by the legal requirements associated with these rights.

Take down policy

The Research Portal is Queen's institutional repository that provides access to Queen's research output. Every effort has been made to ensure that content in the Research Portal does not infringe any person's rights, or applicable UK laws. If you discover content in the Research Portal that you believe breaches copyright or violates any law, please contact openaccess@qub.ac.uk. 


\title{
Pyrolysis Kinetic Modeling of a Poly(ethylene-co-vinyl acetate) Encapsulant Found in Waste Photovoltaic Modules
}

\author{
Charlie Farrell,* Ahmed I. Osman, John Harrison, Ashlene Vennard, Adrian Murphy, Rory Doherty,
} Mark Russell, Vignesh Kumaravel, Ala’a H. Al-Muhtaseb, Xiaolei Zhang, Jehad K. Abu-Dahrieh, and David W. Rooney

Cite This: https://doi.org/10.1021/acs.iecr.1c01989
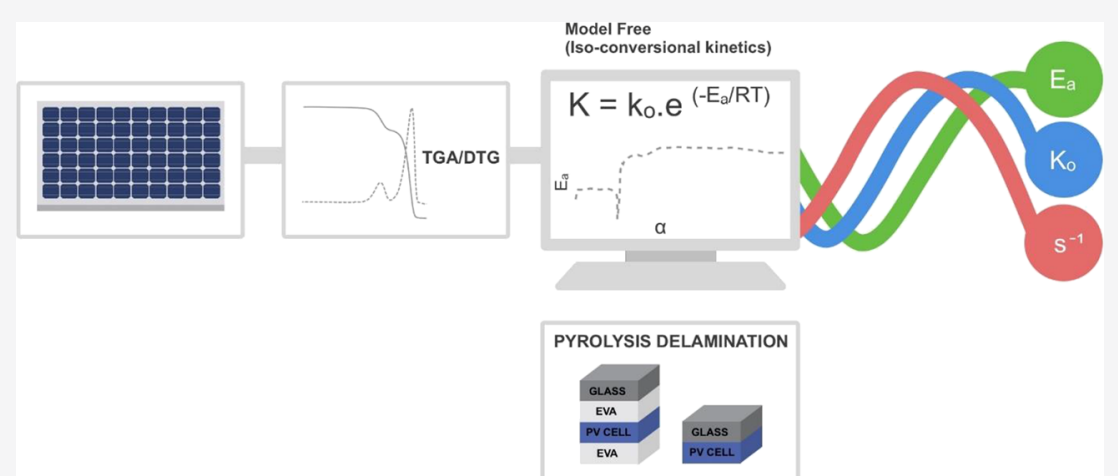

ABSTRACT: As the global cumulative installation of solar photovoltaic (PV) devices grows every year, a proportionate number of waste PV modules arises because of their limited lifespan. It is estimated that by 2050 , there will be approximately $60-78$ million tonnes of PV waste (Farrell, C.; Osman, A. I.; Zhang, X. et al. Sci Rep. 2019, 9, 5267). These modules are bound in a strong encapsulated laminate that is prone to imminent degradation. Subsequently, a form of treatment is required to remove a problematic polymeric material such as the encapsulant poly(ethylene-co-vinyl acetate) (EVA) in order to recycle. Pyrolysis is an ideal option that facilitates clean delamination by removing the polymer fraction, and it does not promote chemical oxidation to any of the constituents left behind after pyrolysis. To date, there are limited studies on the pyrolysis of EVA found in PV modules, resulting in significant gaps in the knowledge of pyrolysis kinetic parameters. This work aims to investigate the pyrolysis reaction kinetics concerning the EVA encapsulant found in end-of-life (EoL) crystalline silicon (c-Si) PV modules. The thermoanalytical technique employed was thermogravimetric analysis, which was carried out at $0.5,1,2,4$, and $5{ }^{\circ} \mathrm{C} \min ^{-1}$ to ensure accuracy and high resolution while analyzing the kinetics. The kinetic triplet was determined and reported for the first time using the Advanced Kinetics and Technology Solutions (AKTS) Thermokinetics software. The main kinetic modeling method employed was the Friedman differential isoconversional method. Other conventional kinetic modeling approaches were also used, such as the integral (Ozawa) and ASTM-E698 methods for comparison of apparent activation energy. It was observed that the activation energy values for each method were 167.66-260.00, 259.70, and 167.00-252.65 kJ mol ${ }^{-1}$ for EVA pyrolysis. Additionally, isothermal, nonisothermal, and step-based predictions were reported for the first time using the thermokinetics package. Furthermore, pyrolysis of EVA can have a triple role in the successful delamination of PV modules, recovery of additional constituents, and aiding of waste management of this problematic polymer.

\section{INTRODUCTION}

Owing to the ever-growing population and increased energy demand, the world is transitioning away from fossil fuels toward renewable energy technologies in order to decarbonize and meet Paris Agreement climate targets. ${ }^{1-3}$ Of these renewable technologies, the solar photovoltaic (PV) devices has gained considerable interest because of their ability to produce electricity without any subsequent noise or air pollution in the form of emissions. ${ }^{4-6}$ As of 2018 , solar has taken the lead for renewable capacity additions at 55\%, surpassing that of its competitive counterparts such as hydropower and wind.

Received: May 24, 2021

Revised: August 2, 2021

Accepted: August 3, 2021 
The solar energy industry is helping to meet the ever-growing global energy demand that is estimated to reach $778 \mathrm{EJ}$ by $2035 .{ }^{8}$ At the end of 2019, the global installed capacity of solar PV passed the threshold of $600 \mathrm{GW} .{ }^{9,10}$ PV modules have a limited lifespan of 25-30 years, and this is also reflected in the manufacturer's guarantee. ${ }^{11-13}$ However, it is worth noting that the lifespan can vary based on the type of the failure mode or degradation experienced by the module. For example, the recent work of Tracy et al. outlines encapsulant adhesion as a function of environmental stressors (UV exposure, temperature, and humidity) with lab and field data in various climates. ${ }^{14}$ As annual installations increase exponentially, so does the waste that will arise. Of the two commercially available generations of PV modules, the first-generation, also known as crystalline silicon (c-Si) PV modules, equates to a market share of $80-90 \%$ over the last 40 years. ${ }^{15,16}$ In 2012, PV modules were added to the EU's WEEE directive, making it a law as of February 14, 2014, that PV manufacturers and suppliers are now responsible for their end-of-life (EoL) management. ${ }^{17-19}$ Despite this legislative driver, approximately only $10 \%$ of PV modules are recycled globally. ${ }^{20}$ To date, there are limited studies available on EoL PV modules considering the effect that it will have in the near future. $^{21,22}$

PV modules consist of numerous material types, such as glass, metals, and polymers. For reference, please refer to Figure S1 in the Supplementary Information for an exploded diagram of a cSi PV module. This mixture of material types makes the recycling of PV modules difficult. However, as the decomposition temperatures of the constituent types are vastly spread, thermal treatment such as pyrolysis can be used to selectively remove individual components. The first material to decompose is the polymeric fraction (EVA and PV Backsheet) of the module at approximately $500{ }^{\circ} \mathrm{C} .^{23}$

Already, there are approximately 25.8 million tonnes of plastic waste generated in Europe every year. ${ }^{24}$ In 2018, 12.4 million tonnes of post-consumer plastic waste were sent for energy recovery, ${ }^{25}$ growing at an average of $4.9 \%$ every year and a $77 \%$ rise from figures reported in $2006 .^{26}$

It is estimated that between 60 and 78 million tonnes of EoL PV modules will be in circulation by $2050 .^{27,28}$ Of these $60-78$ million tonnes, 6.09-7.92 tonnes equate to the waste polymers found in PV modules when considering the 10.15 wt \% that they contribute to the mass of the module. Furthermore, 3.93-5.11 tonnes equate to the waste polymer poly(ethylene-co-vinyl acetate) (also known as EVA), when considering its dominant 6.55 wt \% contribution to the mass of the polymeric fraction of the c-Si PV module. ${ }^{29}$ EVA acts as an encapsulant protecting the solar cells and metal contacts from mechanical shock and moisture and has excellent adhesion properties to the glass and backsheet layers. EVA is also widely used in a plethora of applications, such as cable sheaths, packaging films, hot melt adhesives, and some drug delivery devices. ${ }^{30}$

In addition to this, EVA has been the industry standard for PV module encapsulation since the 1980s, and according to the current ITRPV report, it is expected to continue to be the industry standard until at least 2029 , as there is no available data beyond this point. ${ }^{31-33}$

EVA as a PV encapsulant is used in both first- and secondgeneration PV modules. This means that if the removal of the EVA layer is successful, this can not only help in the issue of waste management of plastics but also help in the recycling of the constituents left behind post-pyrolysis of the PV module.
Throughout a PV module lifespan, EVA is prone to degradation (sometimes referred to as yellowing) over time. As EVA yellows, the transmittance of light reaching the solar cells lowers and this subsequently has a detrimental effect on the power output of the module. Although not fully understood, it is believed this degradation is related and linked to UV light exposure and moisture ingress. ${ }^{32,34,35} \mathrm{~A}$ mechanism has been outlined recently by Tracy et al. which focuses on the underlying degradation processes that are active at a molecular level and which accounts for the competition of chemical reactions such as cross-linking and chain scission in the bulk encapsulant and bond dissociation because of hydrolytic depolymerization at the cell and glass interfaces. ${ }^{14}$ When the power produced by the module is less than $80 \%$ of the wattage quoted at the time of manufacture, the PV module can be considered as EoL. ${ }^{36}$ However, it is worth noting that there are many failure modes of PV modules that can also deem them as EoL. For example, broken solder connections, failure in lamination, or environmental catastrophes such as storms can also affect how a module can be classified as EoL.

The EVA encapsulant found in first-generation c-Si PV modules poses the most significant challenge in the delamination of PV modules and subsequently in the recycling of the other constituents. Some methods that have been previously utilized to remove the EVA fraction are pyrolysis, ${ }^{37-39}$ combustion, ${ }^{40}$ organic solvents, ${ }^{41-43}$ dissolution in acidic media, ${ }^{39}$ high-voltage pulse crushing, ${ }^{44-46}$ and shockwave. ${ }^{47,48}$ To date, pyrolysis has been reported to be one, if not the most effective, method for the removal of waste polymers found in PV modules, removing a significant fraction with little residual material left post-pyrolysis. Additionally, pyrolysis provides the ability not to promote any chemical oxidation or "burn damage" to the other constituents left behind, providing a clean separation of the silicon solar cell, metal contacts, and the front glass layer. Pyrolysis of polymers usually involves the heating of waste polymer materials under an inert atmosphere in the temperature range of $300-900{ }^{\circ} \mathrm{C} .{ }^{49}$ Parameters such as temperature, pressure, residence time, and the employment of a catalyst used in conventional pyrolysis can be altered to optimize product yields of the pyrolysis process. ${ }^{50,51}$ From the previous work, conventional pyrolysis is ideal for treating waste EVA as there is approximately $1 \mathrm{wt} \%$ residual remaining. ${ }^{52}$ A significant drawback in the developmental transition of thermochemical conversion processes from lab to industrial scale is that more quantitative information regarding the chemical reactions in question is needed. An important part of this information is the development of a kinetic model of the given reaction system.

To date, the complete kinetic triplet (activation energy, preexponential factor, and rate) of the pyrolysis of EVA encapsulant found in PV modules is yet to be reported in the literature. The kinetic triplet can benefit reactor design, process modeling of the pyrolysis delamination of PV modules, and aid in the scaling up of the effective recycling processes. To the best of the authors' knowledge, two existing kinetic studies on the EVA encapsulant were found in c-Si PV modules from De-wen et al. and Wang et at. ${ }^{53,54}$ These studies reported activation energies 15 years apart, but differ considerably from one another in terms of results, kinetic modeling methods used, and did not evaluate the kinetic triplet. This could be due to experimental error, a difference in the grade of EVA used in the study, or the kinetic modeling method employed in their study. Additionally, our study is the first to report thermal predictions of the pyrolysis process (isothermal, nonisothermal, and step heating) and to use the 
differential isoconversional method, alongside the integral Ozawa and ASTM E-698 methods. Finally, the use of simulation (via the Advanced Kinetics and Technology Solutions [AKTS] thermokinetics package) may be used to verify and expand the experimental results.

This paper aims to fulfill this requirement and provide a detailed differential isoconversional kinetic model of the pyrolysis of the EVA encapsulant found in c-Si PV modules. This will ultimately help academics and industry considering the rapid delamination of EoL PV modules. Herein, the pyrolysis kinetic parameters for this material, such as activation energy $\left(E_{\mathrm{a}}\right)$, pre-exponential factor $\left(k_{\mathrm{o}}\right)$, and reaction rate, is reported for the first time. These parameters can consequently be used in the design and modeling of chemical reaction systems for the delamination and recycling of PV modules. Additionally, isothermal, nonisothermal, and step predictions are made for the first time for the pyrolysis of EVA. These heating methods are reflective of the potential lab and industrial uptake.

\section{MATERIALS AND METHODS}

2.1. Solar PV Module Description. Two identically used JA Solar (JAM6(L)-60-285/PR) monocrystalline silicon PV modules were utilized for the experimental work conducted in this study. For thermal analysis experiments, the solar cells contained within the module had to be separated. The cells were cut in square orientations using an OMAX water jet cutting machine in the gaps between each of the solar cells, in order to preserve the constituents in the laminate structure. Each cell sample, on average, had dimensions of approximately $160 \times 160$ $\times 4 \mathrm{~mm}$.

2.2. Extraction of EVA Encapsulant from PV Module. Due to the nature of the strong adhesion properties of the EVA encapsulant to the front glass and backsheet layers in the solar cell, it was impossible to isolate and separate the EVA encapsulant layers cleanly at room temperature and so a previously utilized well-controlled thermal process was used. The thermogravimetric analysis (TGA) results ran at $15{ }^{\circ} \mathrm{C}$ $\min ^{-1}$ from 25 to $550{ }^{\circ} \mathrm{C}$ under the nitrogen atmosphere for the decomposition of EVA confirmed that the thermal process employed did not surpass decomposition temperatures so as not to alter the overall structure of the EVA. ${ }^{55,56}$ Following a previously published method, the cells were placed in an oven for $10 \mathrm{~min}$ at $190{ }^{\circ} \mathrm{C}$ for optimum results in facilitating the removal of the polymer fraction of the module by softening the polymers in the laminate structure. ${ }^{37}$ Once the cells were removed from the oven, an incision was made to the side of the solar cell just above the backsheet layer. This was repeated for each side of the cell until the backsheet was able to be manually removed to gain access to the EVA layers. Typically, this allowed for easy separation of the EVA. However, there was variability in the results due to the cooling time, which was dependent on the time taken to delaminate the backsheet from the structure to allow access to the EVA layer. Any areas containing the residual backsheet material were not considered in this study to ensure the purity of EVA and the accuracy of results.

2.3. AKTS Methodology. TGA was carried out under the nitrogen atmosphere using a flowrate of $50 \mathrm{~mL} \cdot \mathrm{min}^{-1}$ with a Netzsch STA 449C Jupiter instrument over a specific temperature range of $20-570^{\circ} \mathrm{C}$ at different constant heating rates of $0.5,1,2,4$, and $5{ }^{\circ} \mathrm{C} \mathrm{min}^{-1}$ to facilitate a minimum heating rate $(\beta)$ ratio of 10 for the AKTS thermokinetics software. The TGA device was also calibrated for buoyancy effects so that weight changes could be quantified. Other calibration experiments were repeated twice to establish reproducibility, with a standard error of $\pm 1{ }^{\circ} \mathrm{C}$. Ultimately, the reliability of the modeling using AKTS thermokinetics relies on accurate and reproducible thermoanalytical data. In our case, the five TGA experiments outlined in this study were found to have a high $R^{2}$ value of 0.99172 . Additionally, the TGA was performed in line with the recommendations for collecting experimental thermal analysis data for kinetic computations published by the International Confederation for Thermal Analysis and Calorimetry (ICTAC). ${ }^{57}$ This was to ensure accurate results and high resolution of data for the kinetic analysis. The changes in mass loss (expressed in \%) were recorded and monitored during the nonisothermal operation. For the purposes of this study, global lumped kinetic models were used in which EVA decomposition is explained in reaction sequences. ${ }^{58}$ However, there are elementary-driven models that exist in the literature that should be considered also. ${ }^{59}$

AKTS was utilized to determine the kinetic triplet for the EVA pyrolysis, primarily using the differential isoconversional method. Additionally, the package was used to apply the integral isoconversional and nonisoconversional kinetic methods such as the Ozawa and ASTM E-698 methods, respectively, as a comparison for the activation energies found.

In isoconversional kinetic methods of TGA data, measured mass losses should be converted into a dimensionless, temperature-dependent mass loss $(\alpha)$, where $0<\alpha<1$, which is shown in eq $4 .^{60}$

The TGA results were imported into AKTS thermokinetics, and the DTG result was evaluated using the derivation function within AKTS. A horizontal baseline was then constructed on each of the DTG signals to adequately cover the portions of the DTG signals that deviated from the flat baseline, indicating a pyrolysis reaction and mass loss for each of the samples. These regions were found to be consistent with our previously published study. ${ }^{37}$

Considering every DTG signal and subsequent constructed baseline to be as denoted as $D(t)$ and $B(t)$, respectively, where $t$ is time in seconds, Important kinetic parameters such as reaction rate (RR) and reaction progress/extent of conversion $(\alpha)$ can be calculated as follows: ${ }^{61}$

Reaction rate:

$$
\frac{d \alpha}{d t}=\frac{(D(t)-B(t))}{\int_{t_{\text {initial }}}^{t_{\text {final }}}(D(t)-B(t)) d t}
$$

Reaction progress $(\alpha)$ :

$$
\alpha(t)=\frac{\int_{t_{\text {initial }}}^{t}(D(t)-B(t)) d t}{\int_{t_{\text {initial }}}^{t_{\text {final }}}(D(t)-B(t)) d t}
$$

Once the baselines were constructed on all the heating rates, baseline optimization was run using 100 optimization loops to ensure the $R^{2}$ value was tending as close to 1 as it could to facilitate the built-in thermokinetic criterium of the package where " $R$ " of all Arrhenius straight lines should be at least 0.99 to ensure accurate and robust kinetic parameter results.

Additionally, the optimization would ensure that the mass loss figure reported for each heating rate was consistent and did not have large deviations because of the manual forming of baselines. A simulation was then constructed on the data obtained using the simulation tab within the package and was found to be a 


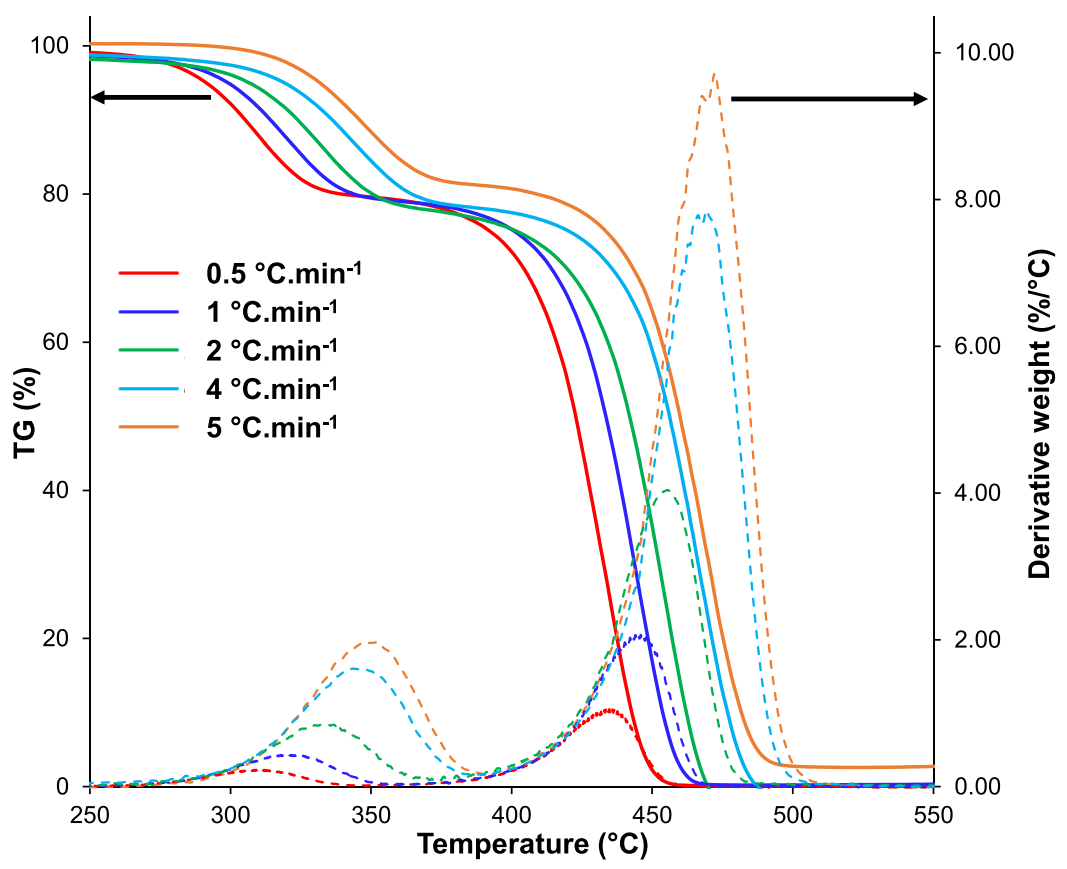

Figure 1. TGA/DTG curves (shown as solid and dashed lines, respectively) of the EVA encapsulant, over a temperature range of $50-550{ }^{\circ} \mathrm{C}$ heated at different heating rates $\left(0.5,1,2,4\right.$, and $\left.5{ }^{\circ} \mathrm{C} \mathrm{min}^{-1}\right)$ under the $\mathrm{N}_{2}$ atmosphere with a flow rate of $50 \mathrm{~mL} \mathrm{~min}$.

close match with some minor deviations, likely due to instrument limitations. Subsequently, 100 optimization loops were applied to the simulated calculations to ensure accuracy and make the results reproducible. Finally, three types of thermal predictions were made using the AKTS thermokinetics software based on the heating regime employed (isothermal, nonisothermal, and step), with parameters such as heating rate, temperature, holding time, $\Delta T$ (change in temperature for each isothermal prediction), and the number of isotherms set by the authors. These types of predictions were selected by the authors to describe the decomposition of PV modules under different heating regimes and scenarios that may occur.

The pre-exponential factor, rate, and activation energy (also known as the kinetic triplet) were calculated from the TGA data $\left(0.5,1,2,4\right.$, and $\left.5{ }^{\circ} \mathrm{C} \mathrm{min}^{-1}\right)$ that was run under the nitrogen atmosphere with a flow rate of $50 \mathrm{~mL} \cdot \mathrm{min}^{-1}$. These results were then used as pre-requisite inputs for the AKTS software.

To date, model-free and model-fitting methods are both used in the literature and are the two most common methods for studying solid-state kinetics using TGA/DSC curves. ${ }^{62}$ Due to the nature of the EVA decomposition, the isoconversional method was utilized as it is better for representing multiple reaction steps and requires no pre-requisite knowledge of the reaction mechanism, ${ }^{63}$ which, to date, is not fully understood in the literature.

The AKTS software was used in order to determine the kinetic triplet in this study using the isoconversional methods such as the Ozawa method ${ }^{64,65}$ and the differential isoconversional methods such as the Friedman method. Additionally, the ASTM-E698 ${ }^{66}$ method was used to show the variation and inaccuracy of predicting EVA pyrolysis kinetic parameters with this method.

The basic theory of the isoconversional principle is outlined herein. The rate of thermal decomposition of the EVA encapsulant can be described in terms of the extent of conversion/reaction progress $(\alpha)$ and temperature $(T)$ as shown in the following equation:

$$
\frac{d \alpha}{d t}=k(T) f(\alpha)
$$

where the decomposed mass fraction of the EVA encapsulant can be denoted as $\alpha$, as shown in the following equation:

$$
\alpha=\frac{m_{\mathrm{i}}-m_{\mathrm{a}}}{m_{\mathrm{i}}-m_{\mathrm{f}}}
$$

where $m_{\mathrm{i}}$ is the initial mass; $m_{\mathrm{a}}$ is the actual mass at time $t$; and $m_{\mathrm{f}}$ is the final mass.

Furthermore, the Arrhenius equation, shown in eq 5, describes the temperature-dependent function in terms of the activation energy and the pre-exponential factor: ${ }^{67}$

$$
k(T)=k_{\mathrm{o}} \times \mathrm{e}(-E \mathrm{a} / R T)
$$

where $k=$ rate coefficient; $T=$ temperature $(\mathrm{K}) ; k_{\mathrm{o}}=$ preexponential factor or frequency factor $\left(\mathrm{min}^{-1}\right) ; E_{\mathrm{a}}=$ activation energy $\left(\mathrm{KJ} \mathrm{mol}^{-1}\right)$; and $R=$ universal gas constant $\left(8.314 \mathrm{~J} \cdot \mathrm{K}^{-1}\right.$ $\left.\mathrm{mol}^{-1}\right)$.

Combining eqs 3 and 5, the equation relating to the solid-state pyrolysis of EVA can be expressed as shown in the following equation: ${ }^{68,69}$

$$
\frac{d \alpha}{d t}=k_{\mathrm{o}} \times \mathrm{e}(-E \mathrm{a} / R T) f(\alpha)
$$

Considering the non-isothermal isoconversional method, the sample is subjected to different constant linear heating rates that are denoted as $\beta$. Additionally, it corresponds to the difference in temperature per unit time as shown in the following equation:

$$
\beta=\frac{d T}{d t}
$$

The heating rate $\beta$ in eq 7 can then be applied to eq 6 as shown in the following equation:

$$
\frac{\mathrm{d} \alpha}{\mathrm{dT}}=\frac{k_{\mathrm{o}}}{\beta} \times \mathrm{e}(-E \mathrm{a} / R T) f(\alpha)
$$




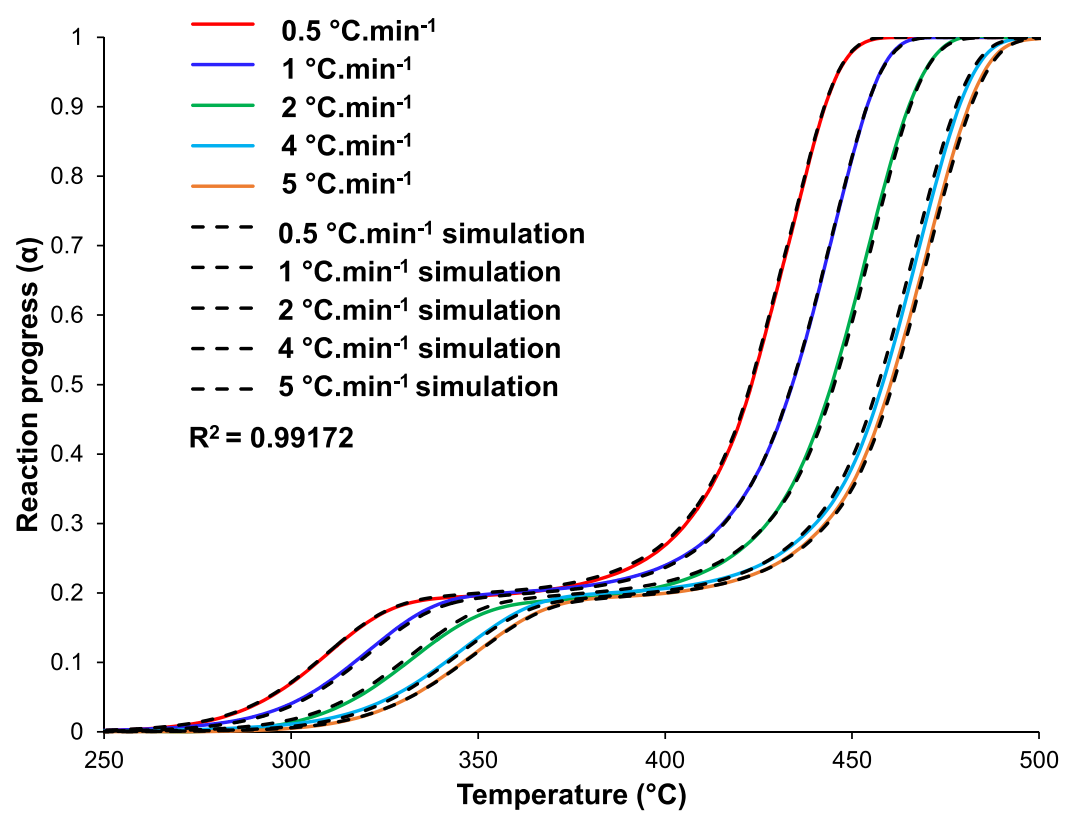

Figure 2. Reaction progress $(\alpha)$ versus the temperature for the EVA encapsulant pyrolysis.

where $f(\alpha)$ refers to the given reaction model.

\section{RESULTS AND DISCUSSION}

3.1. Kinetic Modeling Using TGA. Figure 1 shows the TGA/DTG curves of thermal decomposition of EVA under the nitrogen atmosphere. The five heating rates used $(0.5,1,2,4$, and $\left.5{ }^{\circ} \mathrm{C} \mathrm{min}^{-1}\right)$ throughout the results section are designated by red, dark blue, green, light blue, and orange colors, respectively. From Figure 1, it is evident that there were two main reaction steps in the temperature range of $276-372{ }^{\circ} \mathrm{C}$ and $372-495{ }^{\circ} \mathrm{C}$, respectively. Unsurprisingly, the decomposition temperature was shifted toward a higher temperature by increasing the heating rates from 0.5 to $5{ }^{\circ} \mathrm{C} \mathrm{min}{ }^{-1}$. As reported by $\mathrm{Xu}$ et al., this can be explained by the so-called "temperature hysteresis phenomenon," where a period of time is required for the heat that is transferring from the surface to the inside of the sample, which is longer when higher heating rates are utilized. ${ }^{70}$

To date, the overall mechanism of EVA pyrolysis is not well defined in the literature. The first decomposition stage, however, is well documented and has been referred to extensively as the "acetic acid shelf." ${ }^{53,71}$ This signifies the removal of acetic acid from the EVA structure, and the intermediate which is formed has been reported by De-wen et al. as "polyethylene copolyacetylene." 53 Similarly, Rimez et al. reported on a general deacetylation mechanism of EVA in oxidative and nonoxidative environments. $^{72}$ The breakdown of this intermediate has been said to be the breakdown into smaller hydrocarbons. However, to date, this has not been quantified, or all the final products deduced to provide a complete mechanism of both decomposition stages. The stoichiometry of both these degradation reactions would serve a significant purpose in the modeling and scaling of the pyrolysis process. The rationale of this study and the use of the differential isoconversional method are further supported due to the lack of a clear reaction mechanism in the literature for the EVA utilized in PV modules.

The TGA/DTG results are represented by solid lines and dashed lines in Figure 1, respectively. For the purpose of this study, a portion and not the full thermogram is shown to highlight the temperature range and peaks relating to mass loss in EVA pyrolysis. The results indicated there were two apparent decomposition stages and that both stages had been completed by $500{ }^{\circ} \mathrm{C}$. This is in agreement with the results in the literature. $^{23,52,53,73,74}$ The DTG peaks were visible at lower temperatures than those reported in the literature. For example, in our case, the first and second decomposition peaks were at 312 and $435{ }^{\circ} \mathrm{C}$, whereas Serrano et al. and De-wen et al. reported 340 and $458{ }^{\circ} \mathrm{C}^{74}$ and $\left(345\right.$ and $\left.468{ }^{\circ} \mathrm{C}\right),{ }^{53}$ respectively. However, this is likely due to the heating rates in this study being much lower than reported elsewhere to ensure high acquisition and accuracy in the evaluation of the kinetic triplet. ${ }^{37}$ Once the TGA/DTG results were imported into the AKTS software, and the derivation was applied, a baseline construction was made on each DTG curve using the horizontal method. This enabled the determination of the reaction progress versus temperature for each of the heating rates and the calculation of a coefficient of determination $\left(R^{2}\right)$ value for all the data. The AKTS importations and baseline constructions are shown in Figure S2 in the Supporting Information.

Figure 2 shows the reaction progress $(\alpha)$ of the EVA pyrolysis versus the temperature, where the solid colored curves are for practical experimental results and the dashed black lines are for the theoretical simulated calculations obtained from the AKTS software. It is evident that there is a clear and apparent match between the theoretical and practical results, where $R^{2}$ was of 0.99172. Generally, there were two reaction steps in the temperature range of $276-372$ and $372-495^{\circ} \mathrm{C}$, respectively. These regions were divided based on the inflection point observed at approximately $\alpha=0.2$. This inflection point also agrees with the results shown in Figure 1, where after approximately $20 \%$ of the sample's mass is lost, the second decomposition stage occurs. There was a shift of $\alpha$ at a higher temperature with an increase in the heating rates. Consequently, when increasing the heating rate, an observation should be made in the form of a consistent shift of $\alpha$-T dependences into the direction of the higher temperatures.

For instance, $10 \%$ of the reaction progress $(\alpha=0.1)$ for different heating rates of $0.5,1,2,4$, and $5^{\circ} \mathrm{C} \min ^{-1}$ was shown to happen at $306.2,317.9,329.6,345.9$, and $347.2{ }^{\circ} \mathrm{C}$, 


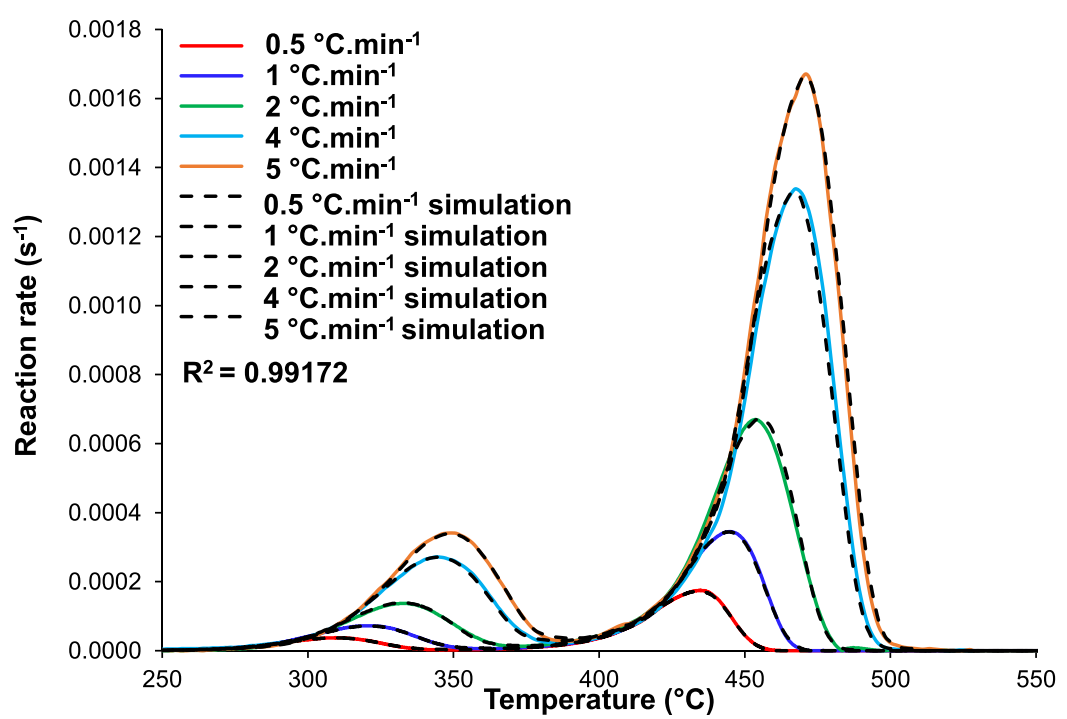

Figure 3. Reaction rate versus the temperature for the EVA encapsulant pyrolysis.

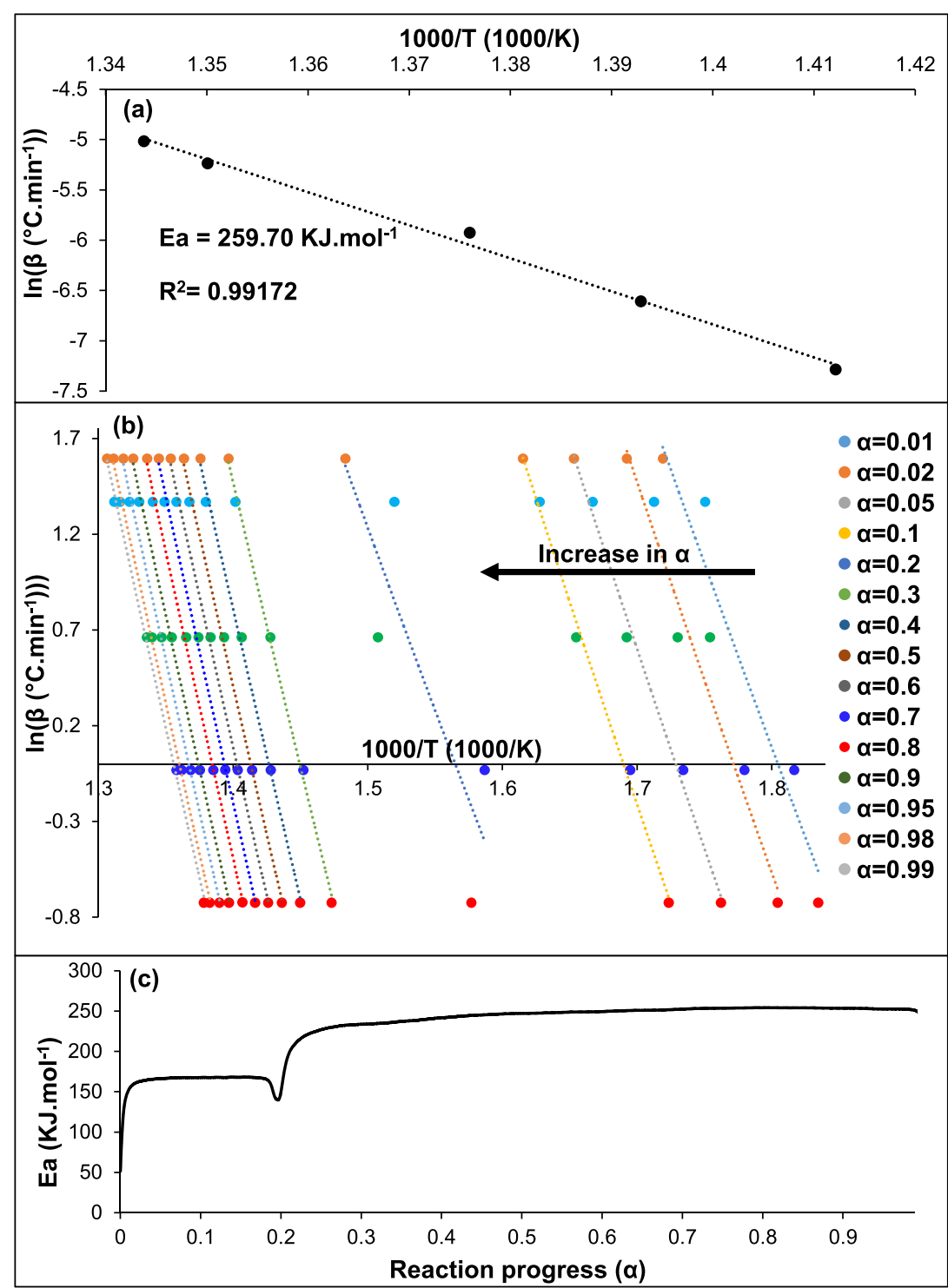

Figure 4. Apparent activation energy calculated by different methods: (a) ASTM-E698 method and (b and c) Ozawa method ln heating rate vs reciprocal temperature and $E_{\mathrm{a}}$ as a function of reaction progress $(\alpha)$, respectively. 


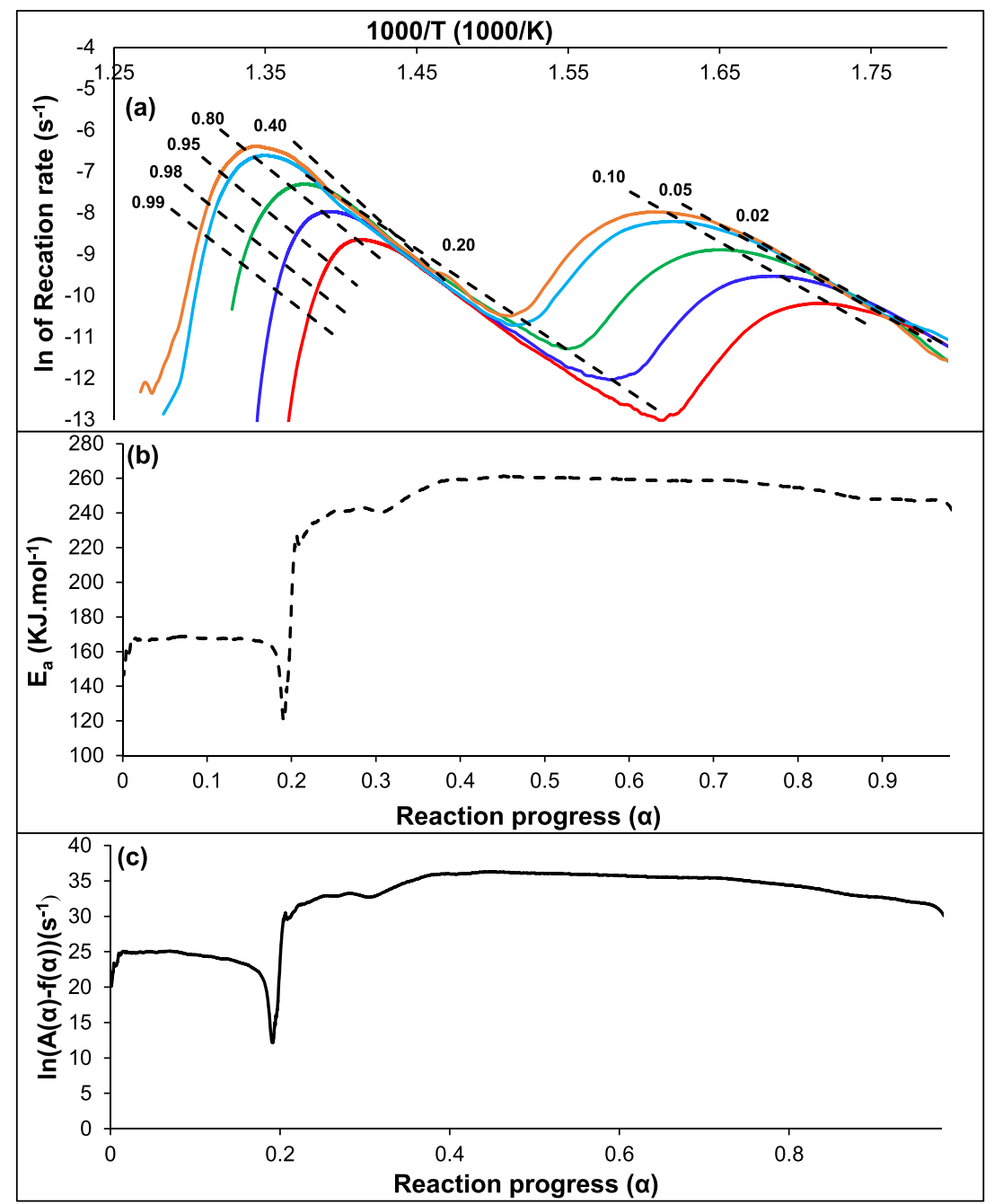

Figure 5. Differential isoconversional method used to calculate the kinetic parameters of EVA pyrolysis: (a) natural logarithm of the reaction rate in $\left(\mathrm{s}^{-1}\right)$ versus the inverse temperature, (b) $E_{\mathrm{a}}$, and (c) $\ln k_{0}$.

respectively. There was around $10{ }^{\circ} \mathrm{C}$ difference between the heating rates of $0.5,1$, and $2{ }^{\circ} \mathrm{C} \mathrm{min}-1$, whereas only $1.3{ }^{\circ} \mathrm{C}$ between 4 and $5{ }^{\circ} \mathrm{C} \mathrm{min}^{-1}$ as shown in Figure 2. The latter is likely due to the close nature of the heating rates $\left(4\right.$ and $5{ }^{\circ} \mathrm{C}$ $\left.\mathrm{min}^{-1}\right)$ as the others are increasing by a factor of two $\left(0.5,1,2{ }^{\circ} \mathrm{C}\right.$ $\left.\min ^{-1}\right)$.

The EVA pyrolysis reaction rate is shown in Figure 3, where the solid colored curves and the dashed black curves represent the practical and theoretical calculations, respectively. The calculations showed a good match with the experimental data for all the heating rates with $R^{2}>0.99$. It is not surprising that the reaction rate shifted toward higher reaction temperature with an increase in the heating rates from 0.5 to $5{ }^{\circ} \mathrm{C} \mathrm{min}{ }^{-1}$ as seen in Figure 3. The maximum RR for the pyrolysis of EVA is clearly in the second decomposition step within the reaction temperature of $372-495{ }^{\circ} \mathrm{C}$. For example, at the heating rates of $0.5,1,2,4$, and $5{ }^{\circ} \mathrm{C} \mathrm{min}{ }^{-1}$, the maximum RRs were of $0.000156,0.000306$, $0.000635,0.001324$, and $0.001626 \mathrm{~s}^{-1}$, respectively. By increasing the heating rates 10 times from 0.5 to $5{ }^{\circ} \mathrm{C} \mathrm{min}{ }^{-1}$, the maximum RRs increased approximately 10 times (10.4).

3.2. Kinetic Modeling Discussion of EVA Pyrolysis. The ASTM-E698 method was used to calculate the apparent activation energy of the EVA pyrolysis and was found to be $259.70 \mathrm{~kJ} \mathrm{~mol}^{-1}$, as shown in Figure 4a. This method can be seen as an extremely limited kinetic modeling method, only producing one discrete activation energy value, exempt of conversion, a major limitation, if there are simultaneous reactions or consecutive reaction steps. ${ }^{66}$ As shown in the TGA/DTG curves in Figure 1, it is evident that the EVA pyrolysis occurs in two decomposition stages; thus, a single $E_{\mathrm{a}}$ value would not be an accurate representation herein. As reported by Wu et al., this error does not appear in the Friedman method. ${ }^{75}$ Consequently, the isoconversional method should be more appropriate in this case as it provides the kinetic parameters in the form of $E_{\mathrm{a}}$ and pre-exponential factor $\left(K_{0}\right)$ as a function of reaction progress $(\alpha)$. Thus, in a more realistic approach, $E_{\mathrm{a}}$ varies during the reaction. Figure $4 \mathrm{~b}$ shows a plot of Ozawa ln (heating rate) versus the inverse temperature across different extents of reaction progress/conversion. From the graph, it is evident that there is a strong match of the results and that the only points that fall outside of the logarithmic trend lines are at $\alpha=0.2$.

Interestingly, this is where the decomposition stage is changing from the first to the second step, and this is likely a reason for the discrepancy in the match. Finally, Figure $4 \mathrm{c}$ shows $E_{\mathrm{a}}$ calculated using the Ozawa method, as a more precise method than that of the ASTM-E698 method. There were two distinct activation energy values observed: $165.00 \mathrm{~kJ} \mathrm{~mol}^{-1}$ at the $\alpha$ 
Table 1. Thermoanalytical EVA Sample Information at Various Heating Rates from 0.5 to $5{ }^{\circ} \mathrm{C} \min ^{-1}$

\begin{tabular}{cccccccc} 
sample heating rate $\left[\beta\left({ }^{\circ} \mathrm{C} \mathrm{min}^{-1}\right)\right]$ & $T_{\text {initial }}\left({ }^{\circ} \mathrm{C}\right)$ & $T_{\text {final }}\left({ }^{\circ} \mathrm{C}\right)$ & mass loss $(\%)$ & integration $(\%)$ & peak height $(\% / \mathrm{min})$ & $T_{\text {peakl }}\left({ }^{\circ} \mathrm{C}\right)$ & $T_{\text {peak2 }}\left({ }^{\circ} \mathrm{C}\right)$ \\
\hline 0.5 & 230.98 & 482.13 & 98.03 & 1.97 & 1.03 & 306.90 \\
1 & 231.19 & 499.30 & 98.75 & 1.25 & 2.05 & 320.38 \\
2 & 231.64 & 527.24 & 98.44 & 1.56 & 3.96 & 344.29 \\
4 & 232.34 & 527.25 & 98.42 & 1.58 & 7.90 & 333.11 \\
5 & 243.95 & 527.41 & 97.64 & 2.36 & 9.79 & 454.12 \\
& & & & &
\end{tabular}

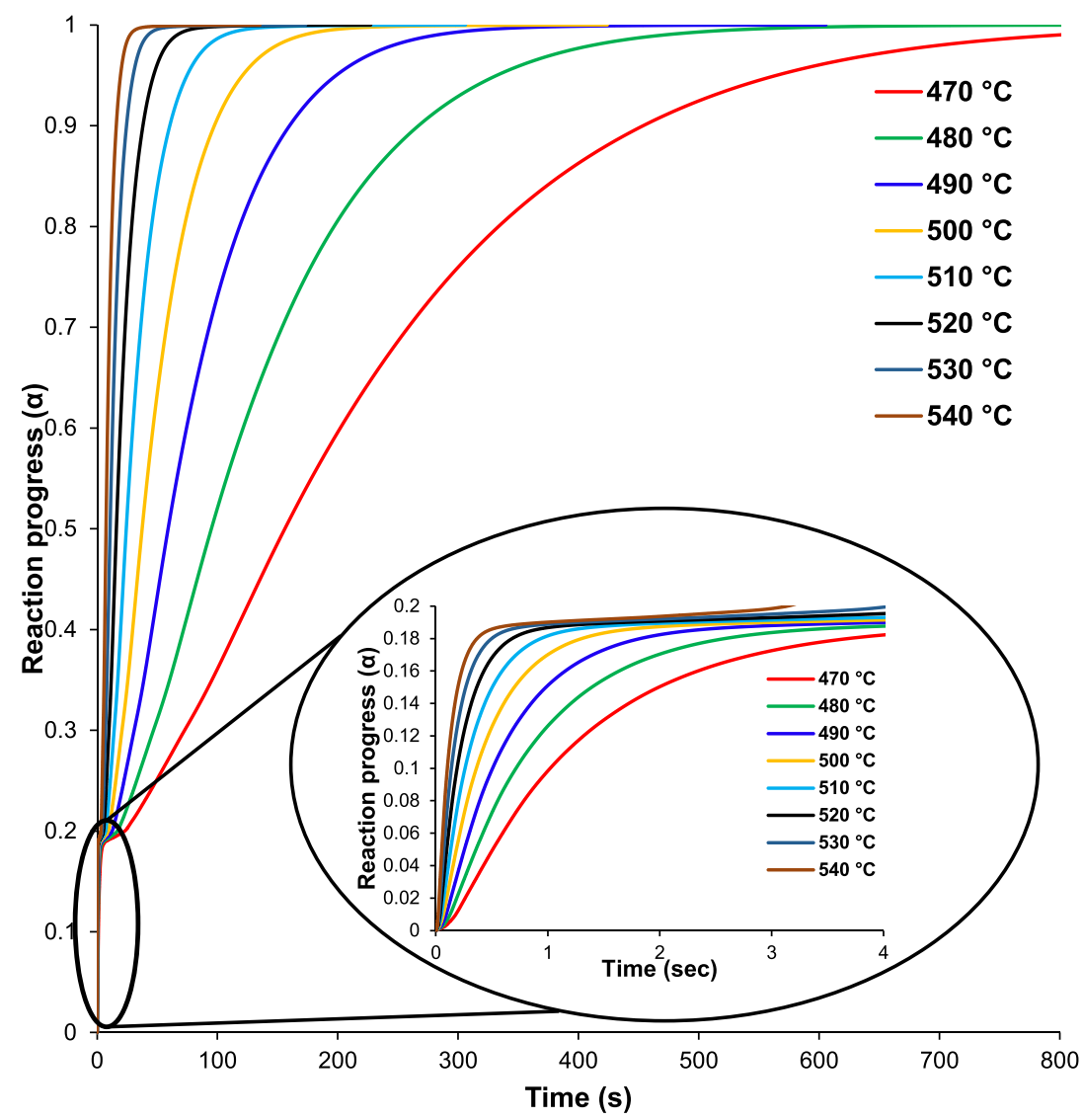

Figure 6. Isothermal prediction of EVA pyrolysis using the AKTS software with isotherms showing the change in reaction progress in the temperature range of $470-540^{\circ} \mathrm{C}$. The inset window shows the isothermal prediction within an $\alpha$ range of $0.0-0.2$.

range of $0.0-0.2$ and $250 \mathrm{~kJ} \mathrm{~mol}^{-1}$ at an $\alpha$ range of $0.2-1.0$. The results are in agreement with the TGA/DTG curves in Figure 1, which showed the two-stage thermal decomposition of EVA pyrolysis.

The AKTS software was used to calculate the kinetic parameters for the pyrolysis of EVA via the differential isoconversional method. Figure 5a shows the natural logarithm of the $\mathrm{RR}$ in $\left(\mathrm{s}^{-1}\right)$ versus the inverse temperature for the different temperatures and heating rates, whereas the calculated $E_{\mathrm{a}}$ and $K_{0}$ are shown in Figure $5 \mathrm{~b}, \mathrm{c}$, respectively. The differential isoconversional analysis allows the discovery of the Arrhenius dependence for any chosen reaction progress $(\alpha)$ as the data are split over 10,000 data points. The slope of the given dependence gives the apparent activation energy and pre-exponential factor at each stage of the overall reaction progress. Again, there were two-stage activation values: $168.00 \mathrm{~kJ} \mathrm{~mol}^{-1}$ at the $\alpha$ range of $0.0-0.2$ and $260.00 \mathrm{~kJ} \mathrm{~mol}^{-1}$ at the $\alpha$ range of $0.2-1.0$. The firststep activation energy is quite similar to that which was calculated from the FWO method $\left(165 \mathrm{~kJ} \mathrm{~mol}^{-1}\right)$, whereas the second-step activation energy is slightly higher than that was calculated with the FWO method $\left(250.00 \mathrm{~kJ} \mathrm{~mol}^{-1}\right)$. In addition, the Ozawa method is potentially less precise due to its results being different to the likes of Friedman if the activation energy depends on the degree of conversion as reported by Venkatesh et al. ${ }^{76}$ However, this is not the case with our analysis, which indicates that the activation energy is independent of the degree of conversion for EVA pyrolysis. An evident inflection point can be seen in Figure 5a at approximately $\alpha=0.2$, which indicates the end of the first decomposition stage and the start of the second stage. This is in agreement with the TGA/DTG results shown in Figure 1 and Table 1, respectively. It has been previously reported that if the activation energy depends on the degree of conversion, its values obtained by isoconversional differential and integral methods are different. ${ }^{76}$

\section{THERMAL PREDICTIONS OF EVA PYROLYSIS}

4.1. The Isothermal Prediction of EVA Pyrolysis. The prediction of the EVA pyrolysis ran under the isothermal operation was calculated using the AKTS software, and the results are shown in Figure 6. The temperature range was set between 470 and $540{ }^{\circ} \mathrm{C}$ due to the range reported in the literature for the optimum pyrolysis temperature used for the 

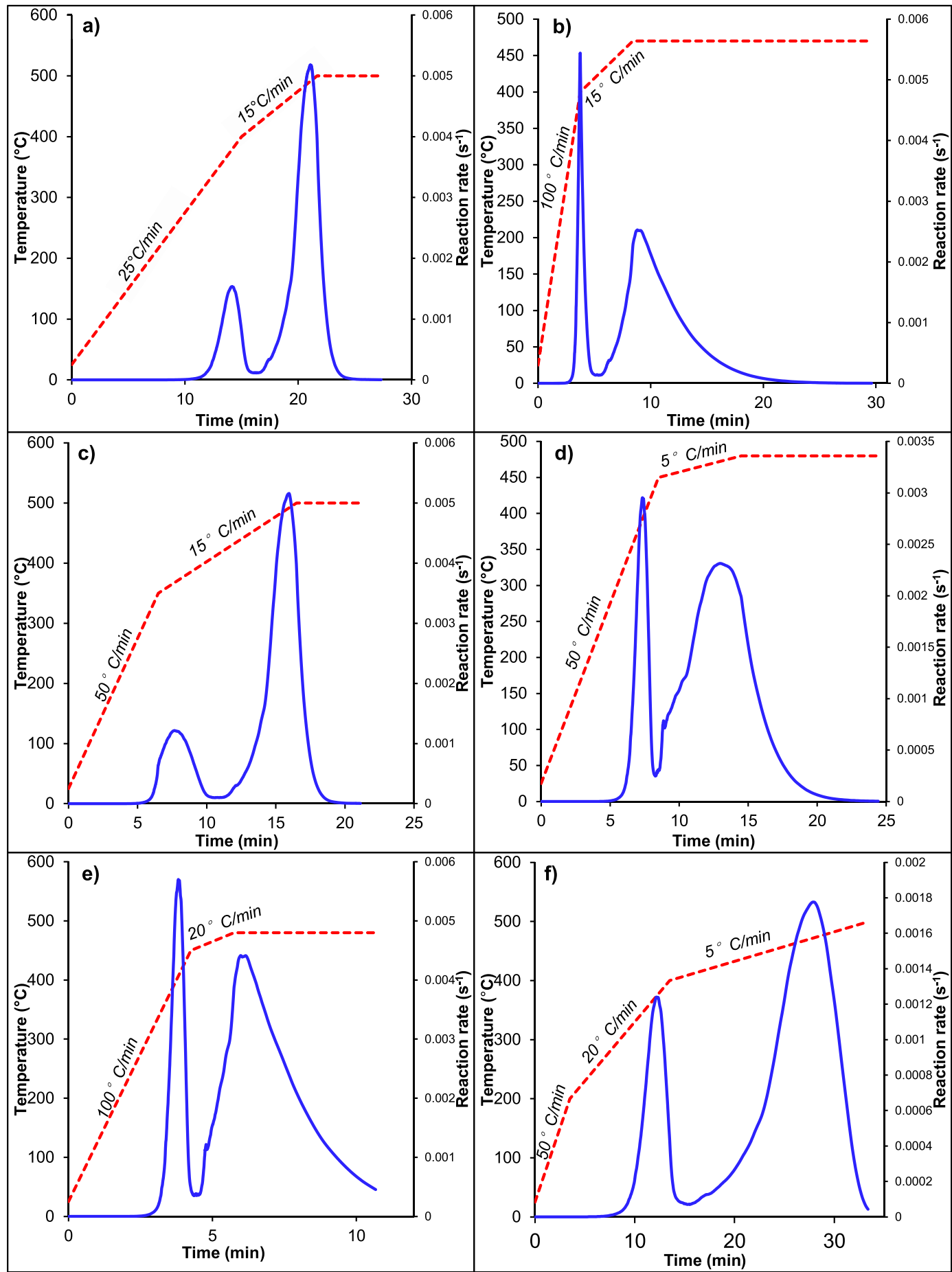

Figure 7. Step prediction of EVA pyrolysis at different temperatures and heating rates.

EVA encapsulant of $480-500{ }^{\circ} \mathrm{C} .{ }^{56}$ For example, Dias et al. reported that at $500^{\circ} \mathrm{C}$ with a hold time of half an hour was ideal for $>99 \%$ removal of the polymeric material in the PV module. ${ }^{23}$ Park et al. had previously stated that, in fact, $480{ }^{\circ} \mathrm{C}$ at a ramp rate of $15{ }^{\circ} \mathrm{C} \mathrm{min}{ }^{-1}$ for half an hour was ideal; however, this was to ensure that constituents such as the silicon wafer were recovered without any damage such as cracking. ${ }^{56}$ Additionally, the $\Delta T$ was set to $10^{\circ} \mathrm{C}$ between the eight isotherms shown.

Due to the rapid decomposition in the first stage at temperatures of $470{ }^{\circ} \mathrm{C}$ (located on the isotherm) and above, an inset window is added to Figure 6 showing the isothermal prediction within a narrow $\alpha$ range of $0.0-0.2$. At a reaction temperature of $470{ }^{\circ} \mathrm{C}$, the reaction reached completion $(\alpha=1)$ after $800 \mathrm{~s}$, whereas at temperatures of 480 and $490{ }^{\circ} \mathrm{C}$, reaction completion occurred after 540 and 320 s, respectively. Beyond the reaction temperature of $500{ }^{\circ} \mathrm{C}$, the time required for the reaction to complete has significantly reduced; for instance, at a temperature of $540{ }^{\circ} \mathrm{C}$, the $\alpha$ value reached 1 after only $48 \mathrm{~s}$, as shown in Figure 6. Even at the start of the reaction within the reaction progress range of $0.0-0.2$, the impact of the isothermal temperature may be seen from the inset window of Figure 6. For example, the time required for $\alpha$ to reach 0.18 has increased 10 times by increasing the reaction temperature from 470 to $540{ }^{\circ} \mathrm{C}$ with values of 0.4 and $4.0 \mathrm{~s}$, respectively. Additionally, the 

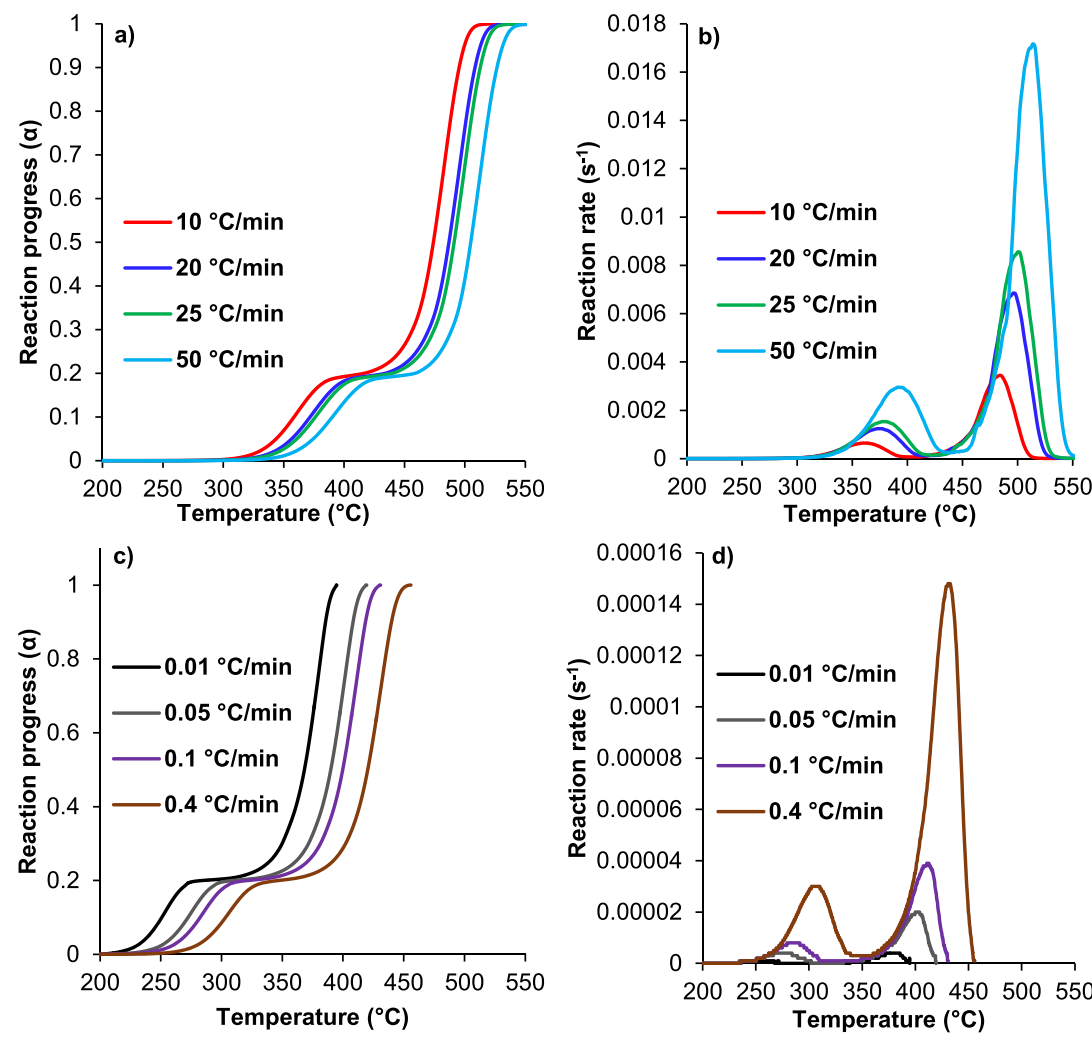

Figure 8. Nonisothermal prediction of EVA pyrolysis at ( $\mathrm{a}$ and $\mathrm{b}$ ) higher heating rates of $10,20,25$, and $50{ }^{\circ} \mathrm{C} \mathrm{min}^{-1}$ and ( $\mathrm{c}$ and $\mathrm{d}$ ) lower heating rates of $0.01,0.05,0.1$, and $0.4^{\circ} \mathrm{C} \mathrm{min}^{-1}$ using the AKTS software.

isothermal predictions outlined herein could be used in applications such as process modeling of EVA pyrolysis to help optimize the PV module delamination process. The isothermal predictions can give us information of residence times for each of the decomposition stages at a given process temperature based on the isotherm they are read from.

4.2. Step-Prediction of EVA Pyrolysis. The stepprediction of EVA pyrolysis at different temperatures and heating rates is shown in Figure $7 \mathrm{a}-\mathrm{f}$. Holding the time for 30 min at the final temperature, the reaction reached completion in $26 \mathrm{~min}$, as shown in Figure 7a. This is in agreement with the work done by Dias et al. that suggested to hold the time for 30 min at $500{ }^{\circ} \mathrm{C}$ for complete pyrolysis of EVA. ${ }^{23}$ However, holding the temperature for only $3 \mathrm{~min}$ is enough to allow the pyrolysis reaction to finish, as shown in Figure 7a. The impact of increasing the heating rate from 25 to $100{ }^{\circ} \mathrm{C} \mathrm{min}{ }^{-1}$ and lower the final temperature from 500 to $470{ }^{\circ} \mathrm{C}$ is shown in Figure $7 \mathrm{~b}$. In this case, the pyrolysis reaction reached completion in $22 \mathrm{~min}$ which is faster than the previous case of $500{ }^{\circ} \mathrm{C}(26 \mathrm{~min})$. In Figure $7 \mathrm{c}$, the reaction completion reached in an even shorter time at $20 \mathrm{~min}$ than the previous cases. This was achieved by increasing the heating rate from 25 to $50{ }^{\circ} \mathrm{C} \mathrm{min}-1$ and then holding the final temperature of $500{ }^{\circ} \mathrm{C}$ for $2.5 \mathrm{~min}$.

On the other hand, by increasing the heating rate from 25 to $50{ }^{\circ} \mathrm{C} \mathrm{min}{ }^{-1}$ and then holding the final temperature of $480{ }^{\circ} \mathrm{C}$ for $7 \mathrm{~min}$, the reaction reached completion after $22 \mathrm{~min}$. Figure 7 e shows that the pyrolysis reaction has not reached completion by increasing the heating rates for both steps and hold the final temperature $480{ }^{\circ} \mathrm{C}$ for $5 \mathrm{~min}$. Finally, Figure $7 \mathrm{f}$ showed that the reaction nearly finished after $33 \mathrm{~min}$ without holding the final temperature but using three heating rates. Thus, the condition in
Figure $7 \mathrm{c}$ showed the best condition to reach the pyrolysis completion in $20 \mathrm{~min}$.

4.3. Nonisothermal Prediction of EVA Pyrolysis. The prediction of nonisothermal EVA pyrolysis using AKTS over noticeably higher heating rates (Figure 8a,b) and lower heating rates (Figure $8 \mathrm{c}, \mathrm{d}$ ) up to a maximum temperature of $550{ }^{\circ} \mathrm{C}$. This prediction profile is quantified with $\alpha$ and the rate of reaction for each predicted heating rate. It is not surprising that the decomposition temperature shifted toward higher reaction temperature, i.e., by increasing the heating rates from 10 to 50 ${ }^{\circ} \mathrm{C} \mathrm{min}^{-1}$, the reaction completions were predicted at 506 and $550{ }^{\circ} \mathrm{C}$, respectively. For the $10{ }^{\circ} \mathrm{C} \mathrm{min}^{-1}$ heating rate, the maximum rate of reaction was $0.0034 \mathrm{~s}^{-1}$ at a temperature of 480 ${ }^{\circ} \mathrm{C}$, whereas at $50{ }^{\circ} \mathrm{C} \mathrm{min}^{-1}$, the maximum rate of reaction was $0.0169 \mathrm{~s}^{-1}$ at $516{ }^{\circ} \mathrm{C}$. Consequently, at high heating rates, by increasing the heating rates by a factor of 5 , the maximum rate of reaction increased by the same factor. Interestingly, by substantially decreasing the heating rates $(0.01-0.4)$, the reaction was predicted to occur at $215-255{ }^{\circ} \mathrm{C}$, which is lower than that at higher heating rates $\left(10-50{ }^{\circ} \mathrm{C} \mathrm{min}^{-1}\right)$ that started at a temperature range of $305-335{ }^{\circ} \mathrm{C}$. Again, the decomposition temperature shifted toward higher reaction temperature; by increasing the heating rates from 0.01 to 0.4 ${ }^{\circ} \mathrm{C} \mathrm{min}^{-1}$, the reaction completions were predicted at 390 and $450{ }^{\circ} \mathrm{C}$, respectively. For the $0.01{ }^{\circ} \mathrm{C} \mathrm{min}^{-1}$ heating rate, the maximum rate of reaction was $0.000007 \mathrm{~s}^{-1}$ at a temperature of $372{ }^{\circ} \mathrm{C}$, whereas at $0.4{ }^{\circ} \mathrm{C} \mathrm{min}{ }^{-1}$, the maximum rate of reaction was $0.00015 \mathrm{~s}^{-1}$ at $433^{\circ} \mathrm{C}$. This means that at very low heating rates, by increasing the heating rates 40 times, the maximum rate of reaction increased 21 times. 


\section{CONCLUSIONS}

As the computer hardware and software significantly advance, so will the complexity and accuracy behind produced pyrolysis kinetic models in the field of thermochemical conversion. The combination of technological advances allows for the building, analyzing, and application of pyrolysis kinetic models such as the one presented in this study.

This paper has provided a complete construction of a novel iso-conversional kinetic model and presented an in-depth analysis of the kinetic triplet (activation energy, pre-exponential factor, and reaction rate) obtained from the pyrolysis of EVA used in an EoL c-Si PV module, which, to the best of our knowledge, has not been reported before. The activation energy and pre-exponential factor using the differential isoconversional method were found to be $167.66-260.00 \mathrm{~kJ} \mathrm{~mol}^{-1}$ and $6.02 \times$ $10^{10}$ to $3.98 \times 10^{15} \mathrm{~s}^{-1}$ in the first and second decomposition stages, respectively. These results help support the idea that the values obtained from the constructed isoconversional model herein will help us to bring scale to the recycling of PV modules via rapid delamination of the EVA encapsulant using the thermochemical conversion method of pyrolysis. The constructed kinetic model can also subsequently be used in other applications such as process modeling to optimize methods to deal with vast volumes of PV modules at an industrial scale for pyrolysis processing. This signifies that if the EVA encapsulant is removed via means of pyrolysis, then it can act as a triple role in:

- The successful and clean delamination of PV modules (through an inert degradation where $>99 \%$ of the EVA is removed).

- Clean delamination allows the recovery of additional constituents such as the glass, metal, and semiconductor layers in the PV module.

- Converting EVA via pyrolysis aids in the waste management of PV modules by providing an alternate EoL pathway for the waste PV polymer and additional constituents as opposed to landfilling.

Additionally, pyrolysis can help facilitate the circular economy and waste management hierarchy of this problematic polymer material by providing an alternative end-of-life pathway instead of imminent landfilling.

\section{ASSOCIATED CONTENT}

\section{SI Supporting Information}

The Supporting Information is available free of charge at https://pubs.acs.org/doi/10.1021/acs.iecr.1c01989.

Images of an exploded c-Si PV module, TGA/DTG AKTS Thermokinetics imports, reaction rate and progress curves, and EVA sample information (PDF)

\section{AUTHOR INFORMATION}

\section{Corresponding Author}

Charlie Farrell - South West College, Cookstown, Northern Ireland BT80 8DN, U.K.; School of Mechanical and Aerospace Engineering, Queen's University Belfast, Belfast, Northern Ireland BT9 5AH, U.K.; (1) orcid.org/0000-0003-28165491; Phone: +44 289097 4412; Email: cfarrell13@ qub.ac.uk; Fax: +442890974687

\section{Authors}

Ahmed I. Osman - School of Chemistry and Chemical Engineering, Queen's University Belfast, Belfast, Northern Ireland BT9 5AG, U.K.; (1) orcid.org/0000-0003-2788-7839
John Harrison - South West College, Cookstown, Northern Ireland BT80 8DN, U.K.

Ashlene Vennard - South West College, Cookstown, Northern Ireland BT80 8DN, U.K.

Adrian Murphy - School of Mechanical and Aerospace Engineering, Queen's University Belfast, Belfast, Northern Ireland BT9 5AH, U.K.

Rory Doherty - School of Natural and Built Environment, Civil Engineering, Queen's University Belfast, Belfast, Northern Ireland BT9 5AG, U.K.

Mark Russell - School of Natural and Built Environment, Civil Engineering, Queen's University Belfast, Belfast, Northern Ireland BT9 5AG, U.K.

Vignesh Kumaravel - Department of Environmental Science, School of Science, Institute of Technology Sligo, Sligo F91 YW50, Ireland; (1) orcid.org/0000-0003-4755-189X

Ala'a H. Al-Muhtaseb - Department of Petroleum and Chemical Engineering, College of Engineering, Sultan Qaboos University, Muscat B1262-900, Oman

Xiaolei Zhang - Department of Chemical and Process Engineering, James Weir Building, University of Strathclyde Glasgow, Glasgow G1 1XJ, U.K.

Jehad K. Abu-Dahrieh - School of Chemistry and Chemical Engineering, Queen's University Belfast, Belfast, Northern Ireland BT9 5AG, U.K.; (1) orcid.org/0000-0003-4005-8779

David W. Rooney - School of Chemistry and Chemical Engineering, Queen's University Belfast, Belfast, Northern Ireland BT9 5AG, U.K.

Complete contact information is available at:

https://pubs.acs.org/10.1021/acs.iecr.1c01989

\section{Notes}

The authors declare no competing financial interest.

The views and opinions expressed in this paper do not necessarily reflect those of the European commission or the Special EU Programmes Body (SEUPB).

\section{ACKNOWLEDGMENTS}

C.F. and A.O. wish to acknowledge the support of South West College and all the Renewable Engine Project partners. The authors are grateful to the School of Natural and Built Environment at Queen's University Belfast (QUB) for the use of the TGA apparatus. This work was funded by the Renewable Engine Project (Project ID IVA5033) and the Bryden Centre (Project ID VA5048), which are supported by the European Union's INTERREG VA Programme, managed by the Special EU Programmes Body (SEUPB), with match funding provided by the Department for the Economy (Northern Ireland) and Department of Enterprise, Trade and Employment (Republic of Ireland). The authors would like to thank Mr. Conaill Doherty and Mrs. Barbara Farrell, who assisted in proofreading this manuscript.

\section{ABBREVIATIONS AND NOMENCLATURE}

AKTS Advanced Kinetics and Technology Solutions

c-Si crystalline silicon

DTG derivative thermogravimetry

$E_{\mathrm{a}} \quad$ activation energy

EoL end-of-life

EU European Union

EVA poly(ethylene-co-vinyl acetate) 
ICTAC International Confederation for Thermal Analysis and Calorimetry

IEA International Energy Agency

IRENA International Renewable Energy Association

ITRPV International Technology Roadmap for Photovoltaics

$k_{\mathrm{o}} \quad$ pre-exponential factor

PV photovoltaics

RR reaction rate

TGA thermogravimetric analysis

UN United Nations

WEEE waste electrical and electronic equipment

$\alpha \quad$ reaction progress

\section{REFERENCES}

(1) Fernández, J. R.; Garcia, S.; Sanz-Pérez, E. S. CO2 Capture and Utilization Editorial. Ind. Eng. Chem. Res. 2020, 59, 6767-6772.

(2) International Renewable Energy Agency - IRENA. Deployment, Investment, Technology, Grid Integration and Socio-Economic Aspects; International Renewable Energy Agency, 2019.

(3) International Energy Agency, I. Market Report Series: Renewables 2018 - English ES; IEA, 2018, 4.

(4) Hsu, D. D.; O’Donoughue, P.; Fthenakis, V.; Heath, G. A.; Kim, H. C.; Sawyer, P.; Choi, J. K.; Turney, D. E. Life Cycle Greenhouse Gas Emissions of Crystalline Silicon Photovoltaic Electricity Generation: Systematic Review and Harmonization. J. Ind. Ecol. 2012, 16, No. S122.

(5) Louwen, A.; van Sark, W. G. J. H. M.; Schropp, R. E. I.; Turkenburg, W. C.; Faaij, A. P. C. Life-Cycle Greenhouse Gas Emissions and Energy Payback Time of Current and Prospective Silicon Heterojunction Solar Cell Designs. Progr. Photovolt.: Res. Appl. 2015, 23, 1406-1428.

(6) Zhang, L.; Ciftja, A. Recycling of Solar Cell Silicon Scraps through Filtration, Part I: Experimental Investigation. Sol. Energy Mater. Sol. Cells 2008, 92, 1450-1461.

(7) Now, R. 21-R. Renewables 2019 Global Status Report; REN21, 2019.

(8) Akor, C. I.; Osman, A. I.; Farrell, C.; McCallum, C. S.; John Doran, W.; Morgan, K.; Harrison, J.; Walsh, P. J.; Sheldrake, G. N. Thermokinetic Study of Residual Solid Digestate from Anaerobic Digestion. Chem. Eng. J. 2021, 406, No. 127039.

(9) ITRPV. International Technology Roadmap for Photovoltaic (ITRPV), Results 2019 Including Maturity Report 2020; ITRPV, 2020.

(10) Deng, R.; Chang, N.; Lunardi, M. M.; Dias, P.; Bilbao, J.; Ji, J.; Chong, C. M. Remanufacturing End-of-life Silicon Photovoltaics: Feasibility and Viability Analysis. Progr. Photovolt.: Res. Appl. 2021, 29, 760.

(11) Centre for remanufacturing \& reuse. The Potential For Remanufacturing of Photovoltaic Solar Cells; 2008, 1-48.

(12) Domínguez, A.; Geyer, R. Photovoltaic Waste Assessment in Mexico. Resour. Conserv. Recycl. 2017, 127, 29-41.

(13) McDonald, N. C.; Pearce, J. M. Producer Responsibility and Recycling Solar Photovoltaic Modules. Energy Policy 2010, 38, 70417047.

(14) Tracy, J.; D’hooge, D. R.; Bosco, N.; Delgado, C.; Dauskardt, R. Evaluating and Predicting Molecular Mechanisms of Adhesive Degradation during Field and Accelerated Aging of Photovoltaic Modules. Progr. Photovolt.: Res. Appl. 2018, 26, 981-993.

(15) Philips, D. S.; Warmuth, W. Fraunhofer ISE: Photovoltaics Report, Updated: 14 March 2019; Fraunhofer ISE, 2019.

(16) Tao, J.; Yu, S. Review on Feasible Recycling Pathways and Technologies of Solar Photovoltaic Modules. Sol. Energy Mater. Sol. Cells 2015, 141, 108-124.

(17) Corcelli, F.; Ripa, M.; Ulgiati, S. End-of-Life Treatment of Crystalline Silicon Photovoltaic Panels. An Emergy-Based Case Study. J. Clean. Prod. 2017, 161, 1129-1142.

(18) Shin, J.; Park, J.; Park, N. A Method to Recycle Silicon Wafer from End-of-Life Photovoltaic Module and Solar Panels by Using Recycled Silicon Wafers. Sol. Energy Mater. Sol. Cells 2017, 162, 1-6.
(19) European Parliament; The Council Of The European Union. Directive 2012/19/EU of the European Parliament and of the Council on Waste Electrical and Electronic Equipment (WEEE). Off. J. Eur. Union 2012, 13, 1-24.

(20) Lunardi, M. M.; Alvarez-Gaitan, J. P.; Bilbao, J. I.; Corkish, R. A Review of Recycling Processes for Photovoltaic Modules. In Solar Panels and Photovoltaic Materials; InTech, 2018.

(21) Mahmoudi, S.; Huda, N.; Behnia, M. Photovoltaic Waste Assessment: Forecasting and Screening of Emerging Waste in Australia. Resour. Conserv. Recycl. 2019, 146, 192-205.

(22) Farrell, C. C.; Osman, A. I.; Doherty, R.; Saad, M.; Zhang, X.; Murphy, A.; Harrison, J.; Vennard, A. S. M.; Kumaravel, V.; AlMuhtaseb, A. H.; Rooney, D. W. Technical Challenges and Opportunities in Realising a Circular Economy for Waste Photovoltaic Modules. Renew. Sustain. Energy Rev. 2020, 128, No. 109911.

(23) Dias, P.; Javimczik, S.; Benevit, M.; Veit, H. Recycling WEEE: Polymer Characterization and Pyrolysis Study for Waste of Crystalline Silicon Photovoltaic Modules. Waste Manag. 2017, 60, 716-722.

(24) European Commission. A European Strategy for Plastics in a Circular Economy. Eur. Com. 2018, 51, 12246.

(25) PlasticsEurope. The Circular Economy for Plastics - A European Overview; PlasticsEurope, 2019.

(26) PlasticsEurope. Plastics - the Facts 2019; PlasticsEurope, 2019.

(27) IRENA, I.-P. End-Of-Life Management: Solar Photovoltaic Panels; International Renewable Energy Agency, 2016.

(28) Deng, R.; Chang, N. L.; Ouyang, Z.; Chong, C. M. A TechnoEconomic Review of Silicon Photovoltaic Module Recycling. Renew. Sustain. Energy Rev. 2019, 109, 532-550.

(29) Corcelli, F.; Ripa, M.; Leccisi, E.; Cigolotti, V.; Fiandra, V.; Graditi, G.; Sannino, L.; Tammaro, M.; Ulgiati, S. Sustainable Urban Electricity Supply Chain - Indicators of Material Recovery and Energy Savings from Crystalline Silicon Photovoltaic Panels End-of-Life. Ecol. Indic. 2018, 94, 37-51.

(30) Lee, Y.; Jeon, K.; Cho, J.; Na, J.; Park, J.; Jung, I.; Park, J.; Park, M. J.; Lee, W. B. Multicompartment Model of an Ethylene-Vinyl Acetate Autoclave Reactor: A Combined Computational Fluid Dynamics and Polymerization Kinetics Model. Ind. Eng. Chem. Res. 2019, 58, 1645916471.

(31) Metz, A.; Demenik, G.; Richter, A. International Technology Roadmap for Photovoltaic (ITRPV) - 2018 Results; ITRPV, 2019, 1-38.

(32) de Oliveira, M. C. C.; Diniz Cardoso, A. S. A.; Viana, M. M.; de Lins, V. F. C. The Causes and Effects of Degradation of Encapsulant Ethylene Vinyl Acetate Copolymer (EVA) in Crystalline Silicon Photovoltaic Modules: A Review. Renew. Sustain. Energy Rev. 2018, 81, 2299-2317.

(33) Peike, C.; Hädrich, I.; Weiß, K.; Dürr, I.; Ise, F. Overview of PV Module Encapsulation Materials. Photovolt. Int. 2013, 22, 85-92.

(34) Omazic, A.; Oreski, G.; Halwachs, M.; Eder, G. C.; Hirschl, C.; Neumaier, L.; Pinter, G.; Erceg, M. Relation between Degradation of Polymeric Components in Crystalline Silicon PV Module and Climatic Conditions: A Literature Review. Sol. Energy Mater. Sol. Cells 2019, 192, $123-133$.

(35) Gagliardi, M.; Lenarda, P.; Paggi, M. A Reaction-Diffusion Formulation to Simulate EVA Polymer Degradation in Environmental and Accelerated Ageing Conditions. Sol. Energy Mater. Sol. Cells 2017, 164, 93-106.

(36) Kazmerski, L. L. Solar Photovoltaics R\&amp;D at the Tipping Point: A 2005 Technology Overview. J. Electron Spectros. Relat. Phenomena 2006, 150, 105-135.

(37) Farrell, C.; Osman, A. I.; Zhang, X.; Murphy, A.; Doherty, R.; Morgan, K.; Rooney, D. W.; Harrison, J.; Coulter, R.; Shen, D. Assessment of the Energy Recovery Potential of Waste Photovoltaic (PV) Modules. Nat. Sci. Rep. 2019, 9, 5267.

(38) Bohland, J. R.; Anisimov, I. I. Possibility of Recycling Silicon PV Modules. In Conference Record of the Twenty Sixth IEEE Photovoltaic Specialists Conference - 1997; IEEE, 1997; 1173-1175.

(39) Bruton, T. M.; Scott, R. D. W.; Nagle, J. P. Recycling of High Value, High Energy Content Components of Silicon PV Modules. Proc. 12th Eur. Photovolt. Sol. Energy Conf 1994, 1994, 459-463. 
(40) Fiandra, V.; Sannino, L.; Andreozzi, C.; Graditi, G. End-of-Life of Silicon PV Panels: A Sustainable Materials Recovery Process. Waste Manag. 2019, 84, 91-101.

(41) Azeumo, M. F.; Conte, G.; Ippolito, N. M.; Medici, F.; Piga, L.; Santilli, S. Photovoltaic Module Recycling, a Physical and a Chemical Recovery Process. Sol. Energy Mater. Sol. Cells 2019, 193, 314-319.

(42) Kang, S.; Yoo, S.; Lee, J.; Boo, B.; Ryu, H. Experimental Investigations for Recycling of Silicon and Glass from Waste Photovoltaic Modules. Renew. Energy 2012, 47, 152-159.

(43) Doi, T.; Tsuda, I.; Unagida, H.; Murata, A.; Sakuta, K.; Kurokawa, K. Experimental Study on PV Module Recycling with Organic Solvent Method. Sol. Energy Mater. Sol. Cells 2001, 67, 397403.

(44) Zhao, P.; Guo, J.; Yan, G.; Zhu, G.; Zhu, X.; Zhang, Z.; Zhang, B. A Novel and Efficient Method for Resources Recycling in Waste Photovoltaic Panels: High Voltage Pulse Crushing. J. Clean. Prod. 2020, 257, No. 120442.

(45) Akimoto, Y.; Iizuka, A.; Shibata, E. High-Voltage Pulse Crushing and Physical Separation of Polycrystalline Silicon Photovoltaic Panels. Miner. Eng. 2018, 125, 1-9.

(46) Song, B. P.; Zhang, M. Y.; Fan, Y.; Jiang, L.; Kang, J.; Gou, T. T.; Zhang, C. L.; Yang, N.; Zhang, G. J.; Zhou, X. Recycling Experimental Investigation on End of Life Photovoltaic Panels by Application of High Voltage Fragmentation. Waste Manag. 2020, 101, 180-187.

(47) GmbH, I. EHF400 Product Series - Technical features; https:// www.impulstec.com/en/products/ehf400-product-series (accessed Jun 20, 2019).

(48) GmbH, I. Selective Separation of Solar Modules Using Shock Wave System: Recycling of Solar Modules; 2018.

(49) Zavala-Gutiérrez, J.; Pérez-Camacho, O.; Villarreal-Cárdenas, L.; Saldívar-Guerra, E. Mathematical Modeling of the Catalytic Pyrolysis of High-Density Polyethylene in a Plug-Flow Tubular Reactor. Ind. Eng. Chem. Res. 2019, 58, 19050-19060.

(50) Gabbar, H.; Aboughaly, M.; Stoute, C. A. DC Thermal Plasma Design and Utilization for the Low Density Polyethylene to Diesel Oil Pyrolysis Reaction. Energies 2017, 10, 784.

(51) Dogu, O.; Pelucchi, M.; Van de Vijver, R.; Van Steenberge, P. H. M.; D'hooge, D. R.; Cuoci, A.; Mehl, M.; Frassoldati, A.; Faravelli, T.; Van Geem, K. M. The Chemistry of Chemical Recycling of Solid Plastic Waste via Pyrolysis and Gasification: State-of-the-Art, Challenges, and Future Directions. Prog. Energy Combust. Sci. 2021, 84, No. 100901.

(52) Dias, P.; Veit, H. Recycling Crystalline Silicon Photovoltaic Modules. In Emerging Photovoltaic Materials; Wiley, 2018; 61-102.

(53) De-wen, Z.; Born, M.; Wambach, K. Pyrolysis of EVA and Its Application in Recycling of Photovoltaic Modules. J. Environ. Sci. 2004, 889-893.

(54) Wang, R.; Song, E.; Zhang, C.; Zhuang, X.; Ma, E.; Bai, J.; Yuan, W.; Wang, J. Pyrolysis-Based Separation Mechanism for Waste Crystalline Silicon Photovoltaic Modules by a Two-Stage Heating Treatment. RSC Adv. 2019, 9, 18115-18123.

(55) Dias, P. R.; Benevit, M. G.; Veit, H. M. Photovoltaic Solar Panels of Crystalline Silicon: Characterization and Separation. Waste Manag. Res. 2016, 34, 235-245.

(56) Park, J.; Kim, W.; Cho, N.; Lee, H.; Park, N. An Eco-Friendly Method for Reclaimed Silicon Wafers from a Photovoltaic Module: From Separation to Cell Fabrication. Green Chem. 2016, 18, 17061714.

(57) Vyazovkin, S.; Chrissafis, K.; Di Lorenzo, M. L.; Koga, N.; Pijolat, M.; Roduit, B.; Sbirrazzuoli, N.; Suñol, J. J. ICTAC Kinetics Committee Recommendations for Collecting Experimental Thermal Analysis Data for Kinetic Computations. Thermochim. Acta 2014, 590, 1-23.

(58) Kruse, T. M.; Wong, H.-W.; Broadbelt, L. J. Mechanistic Modeling of Polymer Pyrolysis: Polypropylene. Macromolecules 2003, 36, 9594-9607.

(59) Moens, E. K. C.; De Smit, K.; Marien, Y. W.; Trigilio, A. D.; Van Steenberge, P. H. M.; Van Geem, K. M.; Dubois, J. L.; D’hooge, D. R. Progress in Reaction Mechanisms and Reactor Technologies for Thermochemical Recycling of Poly(Methyl Methacrylate). Polymers (Basel) 2020, 12, 1667.
(60) Jeraal, M. I.; Roberts, K. J.; McRobbie, I.; Harbottle, D. Assessment of the Thermal Degradation of Sodium Lauroyl Isethionate Using Predictive Isoconversional Kinetics and a Temperature-Resolved Analysis of Evolved Gases. Ind. Eng. Chem. Res. 2019, 58, 8112-8122.

(61) AKTS AG. Advanced Kinetics and Technology Solutions; Siders, Switzerland, 2016.

(62) Osman, A. I.; Abdelkader, A.; Farrell, C.; Rooney, D.; Morgan, K. Reusing, Recycling and up-Cycling of Biomass: A Review of Practical and Kinetic Modelling Approaches. Fuel Process. Technol. 2019, 192, 179-202.

(63) Cai, J.; Alimujiang, S. Kinetic Analysis of Wheat Straw Oxidative Pyrolysis Using Thermogravimetric Analysis: Statistical Description and Isoconversional Kinetic Analysis. Ind. Eng. Chem. Res. 2009, 48, 619-624.

(64) Ozawa, T. A New Method of Analyzing Thermogravimetric Data. Bull. Chem. Soc. Jpn. 1965, 38, 1881-1886.

(65) ASTM International. Standard Test Method for Decomposition Kinetics by Thermogravimetry Using the Ozawa/Flynn/Wall Method. ASTM E1641 2018, 1-7.

(66) ASTM International. Standard Test Method for Kinetic Parameters for Thermally Unstable Materials Using Differential Scanning Calorimetry and the Flynn/Wall/Ozawa Method. ASTM E698 2018, 1-9.

(67) Osman, A. I.; Abdelkader, A.; Johnston, C. R.; Morgan, K.; Rooney, D. W. Thermal Investigation and Kinetic Modeling of Lignocellulosic Biomass Combustion for Energy Production and Other Applications. Ind. Eng. Chem. Res. 2017, 56, 12119-12130.

(68) Díaz, E. G.; González, E.; García, M. F.; Asensio, I. A. Kinetic Study of the Pyrolysis of Canary Pine: The Relationship between the Elemental Composition and the Kinetic Parameters. Ind. Eng. Chem. Res. 2018, 57, 9094-9101.

(69) Osman, A. I.; Young, T. J.; Farrell, C.; Harrison, J.; Al-Muhtaseb, A. H.; Rooney, D. W. Physicochemical Characterization and Kinetic Modeling Concerning Combustion of Waste Berry Pomace. ACS Sustainable Chem. Eng. 2020, 8, 17573-17586.

(70) Xu, X.; Chen, R.; Pan, R.; Zhang, D. Pyrolysis Kinetics, Thermodynamics, and Volatiles of Representative Pine Wood with Thermogravimetry-Fourier Transform Infrared Analysis. Energy Fuel 2020, 34, 1859-1869.

(71) Hrdina, K. E.; Halloran, J. W.; Kaviany, M.; Oliveira, A. Defect Formation during Binder Removal in Ethylene Vinyl Acetate Filled System. J. Mater. Sci. 1999, 34, 3281-3290.

(72) Rimez, B.; Rahier, H.; Van Assche, G.; Artoos, T.; Van Mele, B. The Thermal Degradation of Poly(Vinyl Acetate) and Poly(EthyleneCo-Vinyl Acetate), Part II: Modelling the Degradation Kinetics. Polym. Degrad. Stab. 2008, 93, 1222-1230.

(73) Frisson, L.; Lieten, K.; Declercq, K.; Szlufcik, J.; de Moor, H.; Goris, M.; Benali, A.; Aceves, O. Recent Improvements in Industrial PV Module Recycling. 16th Eur. Photovolt. Sol. Energy Conf.; Routledge, 2000.

(74) Serrano, D.; Aguado, J.; Escola, J.; Rodríguez, J.; Morselli, L.; Orsi, R. Thermal and Catalytic Cracking of a LDPE-EVA Copolymer Mixture. J. Anal. Appl. Pyrolysis 2003, 68-69, 481-494.

(75) Wu, W.; Cai, J.; Liu, R. Isoconversional Kinetic Analysis of Distributed Activation Energy Model Processes for Pyrolysis of Solid Fuels. Ind. Eng. Chem. Res. 2013, 52, 14376-14383.

(76) Venkatesh, M.; Ravi, P.; Tewari, S. P. Isoconversional Kinetic Analysis of Decomposition of Nitroimidazoles: Friedman Method vs Flynn-Wall-Ozawa Method. J. Phys. Chem. A 2013, 117, 1016210169 